\title{
ANALISIS PENGELOLAAN PERUSAHAAN DAERAH ISEN MULANG KOTA PALANGKA RAYA
}

\author{
oleh
}

\author{
Indah Tri Handayani
}

\begin{abstract}
Abstrak
Badan Usaha Milik Daerah (BUMD) perlu dioptimalkan pengelolaannya agar benar-benar menjadi kekuatan ekonomi yang handal sehingga dapat berperan aktif, baik dalam menjalankan fungsi dan tugasnya maupun sebagai kekuatan perekonomian daerah. Laba dari Badan Usaha Milik Daerah (BUMD) diharapkan dapat memberikan kontribusi yang besar terhadap Pendapatan Asli Daerah (PAD). Otonomi daerah memberikan konsekuensi yang cukup besar bagi peran Badan Usaha Milik Daerah (BUMD) dalam menopang Pendapatan Asli Daerah (PAD). Mengingat perannya yang sangat setrategis tentunya Badan Usaha Milik daerah (BUMD) harus dipikirkan secara serius dalam Pengelolaan Perusahaannya dengan merujuk pada tata kelola perusahaan yang baik Good Corporate Governance (GCG). Kota Palangka Raya yang merupakan Ibu Kota Provinsi Kalimantan Tengah salah satu BUMD atau Perusda yang dimiliki yaitu Perusahaan Daerah Isen Mulang (PDIM) beridirinya Perusda ini di atur dalam Peraturan Daerah Kota Palangka Raya Nomor 05 Tahun 2010 Tentang Pembentukan Perusahaan Daerah Di Lingkungan Pemerintah Kota Palangka Raya, di jelaskan maksut dan tujuannya perusahaan daerah dibentuk untuk memberikan wadah usaha secara lebih terencana dan terorganisir dalam rangka mempercepat pembangunan daerah dan untuk membantu pemerintah daerah dalam menciptakan lapangan kerja baru serta meningkatkan kesejahteraan rakyat. serta dalam rangka meningkatkan sumber Pendapatan Asli Daerah (PAD). Jenis usaha yang dijalankan perusahaan daerah isen mulang bergerak di bidang Jasa, Pertanian, Kehutanan, Perkebunan, Pertambangan dan Energi, Properti, Perdagangan dan Industri.
\end{abstract}

Penelitian ini mengkaji tentang Analisis Pengelolaan Perusahaan Daerah Isen Mulang di Kota Palangaka Raya. Obyek penelitian yang dijadikan pokok bahasan penelitian memiliki karakteristik yang rumit dan dinamis mengingat peran dari perusahaan daerah sudah tertuang dalam perda dan dalam pelaksanannya terbatas karena tidak lepas dari faktor kebijakan dan lingkungan organisasi tempat operasionalnya perusahaan. Metode penelitian kualitatif selalu berangkat dari fenomena-fenomena sosial yang di tangkap oleh peneliti, hal ini dikarenakan dalam penelitian kualitatif gejala sosial dan fenomena sudah cukup menjadi syarat dalam penentuan masalah penelitian (Bungin : 2010).

Keterbukaan Transparancy Pelaksanaan prinsip keterbukaan atau transparancy belum terlaksana secara optimal dilihat dari belum adanya web atau blog untuk memudahkan masyarakat mengakses informasi mengenai perusahaan daerah karena dari website lah masyarakat mudah mengakses dan mengetahui perkembangan serta jenis usaha yang dijalankan perusahaan dan hasil kinerja perusahaan. Kejelasan Acountability Pelaksanaan Kejelasan Acountabilty belum terlaksana secara maksimal ini ditandai dengan belum terlaksananya rincian tugas dan tanggung jawab masing-masing organ dalam melaksanakan pekerjaanya.Keseusaian Responsibility Pelaksanaanya mengenai pertanggunga jawaban dan kesesuaian selama beridirinya Perusahaan Daerah Isen Mulang belum pmemberikan kontribusi terhadap PAD secara maksimal karena biaya penyertaan modal itu sebagian besarnya untuk biaya operasional dan PDIM juga pernah memberikan hasil usaha untuk PAD namun itu manyalahi peraturan daerah dikarenakan kondisi Perusahaan masih belum mendapat keuntungan . 
Perusahaan belum melakukan tanggug jawab sosial ditandai belumnya melesatrikan produk lokal, dalam pengelolaan belum dilaksanakan sesuai dengan tujuan dari diberidirikanya PDIM di lingkungan Kota Palangka Raya dan manfaatnya belum benar-benar dirasakan masyarakat, perusahaan belum pernah membayar pajak penghasilan karena kondisnya yang masih minus. Kemandirian Independent Pelaksanaan kemandirian atau Indpendent di Perusahaan Daerah Isen Mulang belum maksimal dilaksanakan ini ditandai dengan adanya pelimpahan tanggung jawab antara yang satu dengan yang lain adapaun yang lainya mengenai pengambilan keputusan sudah baik dengan tandai tidak adanya intervensi dari pihak manapun bebas dari kepentingan dan perusahaan juga diberi kebebasan untuk melakukan jenis usaha, namun permasalahanya terkendala pada biaya yaitu modal usaha, artinya modal yang diberikan kurang, sebagian besar dipergunakan ntuk biaya operasional. kemudian dalam pengangkatan direksi sudah baik dengan dilaksanakanya car-cara yang ideal terlebih dahulu untuk mendapatkan sumberdaya manusia yang profesional.Keadilan

Fairness Pelaksanaan Keadilan Fairness belum terlaksana dengan maksimal yaitu ditandai dengan belum dilaksanakanya pelatihan dan pengembangan pegawai dikarenakan biaya yang mahal telah sama kita ketahui bahwa Pelatihan dan Pengembangan ini sangat penting untuk keberlangsungan perusahaan dalam persaingan yang saat ini semakin ketat, jika tidak dilakukan Pelatihan dan pengembangan pegawai maka pengetahuan disiplin ilmu pegawai tidak berkembang, tidak memilki motivasi kerja yang tinggi yang ditandai dengan menurunya produktivitas kerja, kualitas kerja menurun, sikap moral dan semangat bekerja berkurang, jadi sebenarnya tidaklah merugi jika perusahaan menggelontorkan dana yang cukup banyak untuk kegiatan pelatihan dan pengembangan pegawai dan dalam perekrutan pegawai belum diumumkan ke masyarakat luas masih pada sistem kekeluargaan karena terkendala dengan biaya.

\section{PENDAHULUAN}

Dalam upaya penguatan penerimaan daerah yang bersumber dari kekayaan daerah yang dipisahkan, maka peranan investasi Pemerintah melalui Badan Usaha Milik Daerah (BUMD) yang diwujudkan dalam bentuk Perusahaan Daerah sangat diharapkan, selain sebagai sumber PAD, BUMD diharapkan juga sebagai pemacu utama pertumbuhan dan pembangunan ekonomi daerah. Perusahaan daerah memiliki peranan yang penting dalam menghasilkan pendapatan bagi daerah.

Kewenangan pemerintah daerah untuk membentuk dan mengelola BUMD diatur dalam Pasal 16 ayat (2) Undang-Undang Nomor 32 Tahun 2004 tentang Pemerintah Daerah yang dinyatakan bahwa bidang pemerintahan yang wajib dilaksanakan oleh kabupaten dan daerah kota meliputi pekerjaan umum, kesehatan, pendidikan dan kebudayaan, pertanian, perhubungan, industri, dan perdagangan, penanaman modal, lingkungan hidup, pertanahan, koperasi dan tenaga kerja. Ketentuan diatas semuanya bernafaskan otonomi daerah yang bertujuan untuk memberdayakan daerah dengan memaksimalkan pengelolaan sumberdaya yang dimiliki. BUMD sebagai perangkat atau sarana yang dimilki daerah diharapkan mampu mendorong serta menggerakkan perekonomian daerah. Badan Usaha Milik Daerah (BUMD) perlu dioptimalkan pengelolaannya agar benar-benar menjadi kekuatan ekonomi yang handal sehingga dapat berperan aktif, baik dalam menjalankan fungsi dan tugasnya maupun sebagai kekuatan perekonomian daerah. Laba dari Badan Usaha Milik Daerah (BUMD) diharapkan dapat memberikan kontribusi yang besar terhadap Pendapatan Asli Daerah (PAD). Otonomi daerah memberikan konsekuensi yang cukup besar bagi peran Badan Usaha Milik Daerah (BUMD) dalam menopang Pendapatan Asli Daerah (PAD). 
Mengingat perannya yang sangat setrategis tentunya Badan Usaha Milik daerah (BUMD) harus dipikirkan secara serius dalam Pengelolaan Perusahaannya dengan merujuk pada tata kelola perusahaan yang baik Good Corporate Governance (GCG).bangan dan Energi, Properti, Perdagangan dan Industri.

Dengan adanya payung hukum dan visi misi yang jelas Perusahaan Isen Mulang dalam pengelolaan seharusnya dapat terlaksana dengan maksimal dan dapat memberikan kontribusi terhadap pendapatan asli daerah serta manfaat keberadaan perusda dapat dirasakan masyarakat Kota Palangka Raya namun kenyataanya hingga saat ini keberadaan Perusahaan Daerah Isen Mulag (PDIM) selama ini belum mampu memberikan kontribusi yang signifikan terhadap PAD, justru lebih banyak suntikan dana dari pemerintah daerah daripada keuntungan yang di peroleh. Kondisi tersebut menjadi beban bagi APBD sehingga apa yang menjadi tujuan berdirinya BUMD adalah sebagai salah satu sumber pendapatan pemerintah daerah belum terlaksana dengan baik.

Mengingat pentingnya BUMD dalam pengelolaan potensi daerah dan sebagai pelayanan masyarakat maka dalam pengelolaannya harus dilakukan dengan baik sesuai dengan prinsip tata kelola perusahaan yang baik sebagai dasar pedoman pengelolaan perusahaan daerah.

Dari penjelasan di atas, maka peneliti tertarik untuk meneliti tentang "Analisis Pengelolaan Perusahaan Daerah Isen Mulang Kota Palangka Raya".

\section{METODOLOGI}

\section{A. Badan Usaha Milik Daerah}

Badan Usaha Milik Daerah (BUMD) adalah perusahaan yang didirikan dan dimiliki oleh pemerintah daerah. Kewenangan pemerintah daerah membentuk dan mengelola BUMD ditegaskan dalam Peraturan Pemerintah No. 25 Tahun 2000 tentang kewenangan pemerintah dan kewenangan provinsi sebagai daerah otonom.

\section{a. Ciri-Ciri BUMD}

(1) Didirikan berdasarkan peraturan daerah (perda) (2) Dipimpin oleh direksi yang diangkat dan diberhentikan oleh kepala daerah atas pertimbangan DPRD. (3) Masa jabatan direksi selama empat tahun (4) Bertujuan memupuk pendapatan asli daerah guna membiayai pembangunan daerah.

\section{a. Tujuan Pendirian BUMD}

(1) Memberikan sumbangsih pada perekonomian nasional dan penerimaan kas negara (2) Mengejar dan mencari keuntungan (3) Pemenuhan hajat hidup orang banyak (4) Perintis kegiatan-kegiatan usaha (5) Memberikan bantuan dan perlindungan pada usaha kecil dan lemah.

Badan Usaha Milik Daerah (BUMD) adalah perusahaan milik pemerintah daerah yg didirikan dengan Peraturan Daerah berdasarkan Undang-Undang No. 5 tahun 1962 dgn modal seluruh atau sebagian merupakan kekayaan daerah yg dipisahkan. 


\section{A. Perusahaan Daerah Isen Mulang (PDIM)}

Berdasarkan peraturan daerah kota palangka raya nomor 05 tahun 2010 tentang pembentukan perusahaan daerah di lingkungan pemerintah kota palangka raya. bahwa salah satu upaya dalam rangka mendorong dan mempercepat pembangunan daerah bidang perekonomian adalah dengan mengembangkan dan memberdayakan perusahaan daerah sebagai salah satu sumber pendapatan bagi daerah, sebagaimana maksud ialah membentuk perusahaan daerah yang bergerak di bidang Jasa, Pertanian, Kehutanan, Perkebunan, Pertambangan dan Energi, Properti, Perdagangan dan Industri. Dengan berdasarkan pertimbangan, maka perlu ditetapkan dengan peraturan daerah kota palangka raya tentang pembentukan perusahaan daerah di lingkungan pemerintah kota palangka raya.

Dengan adanya peraturan daerah ini dibentuk maka perusahan daerah yang berbadan hukum dan berstatus sebagai badan usaha milik daerah. Dan berada di bawah dan bertanggung jawab kepada walikota. Perusahaan daerah ini bernama isen mulang yang berkedudukan di kota plangka raya, mempunyai wilayah kerja/usaha di dalam daerah dan dapat dikembangkan sampai keluar daerah. apabila dianggap perlu perusahaan daerah dapat membentuk cabang di dalam daerah maupun di luar daerah.

1. Maksud dan tujuan dan bidang usaha Adapun maksut dan tujuannya dijelaskan pada pasal 05 dan Pasal 06 yaitu :

a.Perusahaan Daerah dibentuk dengan maksud untuk memberikan wadah usaha secara lebih terencana dan terorganisir dalam rangka mempercepat pembangunan daerah serta dalam rangka meningkatkan sumber Pendapatan Asli Daerah (PAD).

b.Perusahaan Daerah bertujuan untuk membantu Pemerintah Daerah dalam menciptakan lapangan kerja baru serta meningkatkan kesejahteraan rakyat.

\section{A. Tata Kelola Perusahaan Yang Baik (Good Corporate Governance)}

Tata kelola perusahaan yang baik atau Good Corporate Governance (GCG) telah dibuktikan mampu meningkatkan efisiensi dan performa perusahaan yang menerapkannya. Good Corporate Governance adalah seperangkat peraturan yang mengatur hubungan antara pemegang saham, pengurus (pengelola) perusahaan, pihak kreditur, pemerintah, karyawan serta para pemegang kepentingan intern dan ekstern lainnya yang berkaitan dengan hak-hak dan kewajiban mereka, atau dengan kata lain suatu sistem yang mengatur dan mengendalikan perusahaan (Joni emrizon:2007).

Good Corporate Governance juga dapat diartikan sebagi suatu hal yang berkaitan dengan pengambilan keputusan yang efektif yang bersumber dari budaya perusahaan, etika, sistem nilai, proses bisnis, kebijakan dan struktur organisasi yang bertujuan untuk mendorong pertumbuhan kinerja perusahaan, pengelolaan sumber daya dan resoco secara lebih efisien dan efektif serta pertanggungjawaban perusahaan kepada pemgang saham dan stakeholder (Antonius $2004: 31$ ). 
Good Corporate Governance secara umum dikenal sebagai suatu sistem dan struktur yang baik untuk mengelola perusahaan dengan tujuan meningkatkan nilai pemegang saham serta mengakomodasi berbagai pihak yang berkepentingan dengan perusahaan (stakeholders), seperti kreditur, pemasok, asosiasi bisnis, konsumen, pekerja, pemerintah, dan masyarakat luas (Amin Widjaya,2008:41). Prinsip Good Corporate Governance ini dapat digunakan untuk melindungi pihak-pihak minoritas dari pengambil alih yang dilakukan oleh para manajer dan pemegang saham dengan mekanisme legal.

Good Corporate Governance (GCG) merupakan suatu struktur yang diterapkan agar perusahaan dapat semakin berkembang dan terus meningkatkan kinerja dengan didasari oleh perundang-undangan dan nilai-nilai etika. Sebagaimana disampaikan (Sutedi:2011) dalam bukunya Good Corporate Governance (GCG), dijelaskan bahwa definisi Good Corporate Governance (GCG) menurut Cadbury adalah mengarahkan dan mengendalikan perusahaan agar tercapai keseimbangan antara kekuatan dan kewenangan perusahaan. Berkaitan dengan nilai-nilai etika yang mendasari kegiatan bisnis sebagaimana disebutkan sebelumnya, terdapat lima prinsip-prinsip Good Corporate Governance (GCG) menurut kementrian BUMN yaitu TARIF: transparency (keterbukaan), accountability (akuntabilitas), responsibility (pertanggungjawaban), independency (kemandirian) dan fairness (kewajaran).

PER-01/MBU/2011 tentang Penerapan Tata Kelola Perusahaan Yang Baik (good corporate governance) Pada Badan Usaha Milik Negara. Dalam Pasal 1 (1) disebutkan: Tata Kelola Perusahaan yang Baik (Good Corporate Governance), yang selanjutnya disebut GCG adalah prinsip-prinsip yang mendasari suatau proses dan mekanisme pengelolaan perusahaan berlandaskan peraturan perundang - undangan dan etika berusaha (Ahyar Ari Gayo 2013 : 2526).Untuk prinsip-prinsip GCG diatur dalam pasal 3 yaitu :

\section{Keterbukaan (transparency)}

Keterbukaan dalam melaksanakan proses pengambilan keputusan dan keterbukaan dalam mengungkapkan informasi materiil dan relevan mengenai perusahaan, Hak pemegang saham, yang harus diberi informasi benar dan tepat waktu mengenai perusahaan, dapat berperan serta dalam pengambilan keputusan mengenai perubahan mendasar atas perusahaan dan memperoleh bagian keuntungan perusahaan (Ari Gayo:2013). Dan Pengungkapan yang akurat dan tepat waktu serta transparansi mengenai semua hal penting bagi kinerja perusahaan, kepemilikan, serta pemegang kepentingan (Sutedi : 2012). Prinsip ini diwujudkan antara lain :

a. Mengembangkansistem informasi akuntansi yang berbasiskan standar akuntansi

b. Mengembangkan informasi teknologi dan management information system untuk menjamin adanya pengukuran kinerja yang memadai dan proses pengambilan keputusan yang efektif oleh Dewan Komisaris dan Direksi.

c. Mengumumkan jabatan yang kosong secara terbuka.

\section{Akuntabilitasi (accountability)}

Akuntabilitasi adalah kejelasan fungsi, pelaksanaan dan pertangungjawaban organ sehingga pengelolaan perusahaan terlaksana secara efektif (Ari Gayo:2013).Akuntabilitas adalah Tanggung jawab manajemen melalui pengawasan efektif berdasarkan keseimbangan kekuasaan antar manajer, pemegang saham, dewan komisaris, dan auditor, merupakan bentuk pertanggungjawaban manajemen kepada perusahaan dan pemegang saham (Sutedi : 2012). 
Prinsip ini diwujudkan antara lain :

a. menyiapkan laporan keuangan pada waktu yang tepat dan dengan cara yang tepat.

b. Mengembangkan Komite Audit dan risiko untuk mendukung fungsi pengawasan oleh Dewan Komisaris.

c. Mengembangkan dan merumuskan kembali peran dan fungsi.

\section{Pertangungjawaban (responsibility)}

Pertanggungjawaban atau kesesuaian adalah dalam pengelolaan perusahaan terhadap peraturan Perundang- undangan dan prinsip-prinsip korporasi yang sehat (Ari Gayo:2013). Bentuk dari pertanngunga jawban dalah peran pemegang saham harus diakui sebagaimana ditetapkan oleh hukum dan kerjasama yang aktif antara perusahaan serta pemegang kepentingan dalam menciptakan kekayaan, lapangan kerja, dan perusahaan yang sehat dari aspek keuangan. Prinsip ini diwujudkan antara lain :

a. Tanggung jawab merupakan konsekuensi logis dari adanya wewenang.

b. Menyadari akan adanya tanggung jawab social.

c. Menghindari penyalahgunaan kekuasaan.

d. Memelihara lingkungan bisnis yang sehat.

\section{Kemandirian (independency)}

Kemandirian atau Independency adalah keadaan di mana perusahaan dikelola secara profesional tanpa benturan kepentingan dan pengaruh/tekanan dari pihak manapun yang tidak sesuai dengan peraturan perundang-undangan dan prinsip-prinsip korporasi yang sehat(Ari Gayo:2013)..

\section{Keadilan (fairness)}

Kewajaran adalah keadilan dan kesetaraan di dalam memenuhi hak-hak Pemangku Kepentingan (stakeholders) yang timbul berdasarkan perjanjian dan peraturan perundangundangan(Ari Gayo:2013).. kewajaran atau keadilan dalah perlakuan yang sama terhadap pemegang saham, terutama kepada pemegang saham minoritas dan pemegang saham asing, dengan keterbukaan informasi yang penting serta melarang pembagian untuk pihak sendiri dan perdagangan saham oleh orang dalam (Sutedi : 2012).

Prinsip ini diwujudkan antara lain :

a. Dengan membuat peraturan korporasi yang melindungi kepentingan minoritas.

b. Membuat pedoman perilaku perusahaan (corporate conduct) dan atau kebijakankebijakan yang melindungi korporasi terhadap perbuatan buruk orang dalam dan konflik kepentingan.

c. Menetapkan peran dan tanggung jawab Dewan Komisaris dan Direksi. 


\section{HASIL DAN PEMBAHASAN}

\section{Usaha yang dikelola Perusahaan Daerah Isen Mulang}

\section{jasa Angkutan}

perusahaan membeli truck untuk di investasikan dangan usaha penjulan dan pengangkutan material berupa tanah urug/granit, pasir pasang, batu split/krikil dan batu belah namun kondisinya saat ini keuda unit truck rusak dan rencana akan di hapuskan.

\section{Perdagangan bahan bangunan}

pada tahun 2016 telah ditetapkan fokus utama perusahaan adalah dalam bidang usaha penjualan bahan bangunan, sejak bulan Januari sampai dengan bulan Desember tahun 2016, PDIM melakukan usaha ini secara door to door dengan menerapkan pada Direksi dan Karyawan PDIM sebagai agen-agen pemasaran, hasilnya cukup menggembirakan dan terlihat tren peningkatan atas hasil penerimaan usaha tersebut. Selanjutnya untuk meningkatkan lagi hasil penerimaan dari unit usaha penjualan bahan bangunan ini, maka perusahaan berupaya untuk medirikan 1 (satu) unit toko sederhana semi permanen di atas tanah sewa, yang akhirnya telah mulai beroperasi sejak bulan november 2016.

\section{Perdagangan Hasil Hutan Rotan}

Di awal tahun 2016 Perusahaan pernah melakukan kegiatan pengiriman rotan ke Ubud Bali untuk memenuhi permintaan pengrajin rotan disana. Selanjtnya sesuai dengan RKAP tahun 2016, karena bidang utama yang harus dikembangkan dan dilaksanakan diarahkan untuk bergerak di bidang usaha perdagangan bahan bangunan, maka kegiatan pengiriman rotan tersebut sementara tidak berlanjut lagi, disamping memang belum adanya lagi permintaan dari para pengrajin disana.

\section{Jasa Penjualan Tiket Pesawat}

Jasa Penjualan Tiket Pesawat dengan cara perusahan menyediakan pelayanan penjualan tiket pesawat semua maskapai ke semua tujuan yang tersedia, sasaran penjualan tiket adalah untuk masyarakat umum dan untuk para ASN Pemko Palangka Raya. Hasilnya belum maksimal karena di ersa saat ini sudah banyak aplikasi pembelian secara online dan gerai pelayanan penjualan tiket dan juga tidak semua ASN Pemko Palngka Raya untuk perjalanan dinasnya membeli tiket pesawat ke PD.Isen Mulang. Jasa Pembayaran Online

Jasa Pembayaran Online dengan cara perusahaan menjalankan usaha penerimaan pembayaran listrik, air bersih, telepon dan internet secara online dengan sasaran masyarakat umum dan Pemko Palangka Raya. Namun hasilnya belum maksimal dengan banyaknya aplikasi online dan gerai untuk melakukan pembayaran online. 


\section{HASIL PEMBAHASAN}

\section{Pengelolaan Perusahaan Daerah Isen Mulang Kota Palangka Raya Berdasarkan Tata Kelola Perusahaan Yang Baik Good Corporate Governance (GCG).}

Dengan adanya penelitian ini penulis bermaksud untuk mengetahui Pengelolaan di Perusahaan Daerah Isen Mulang Kota Palangka Raya yang sesuai dengan Peraturan Daerah Kota Palangka Raya dan Tata Kelola Perusahaan Yang Baik. Hasil penelitian ini penulis mendeskripsikan hasil pengamatan, wawancara dan temuan yang diperoleh selama penelitian. Penulis juga mengajukan pertanyaan kepada informan terkait dengan pengetahuan nara sumber mengenai Pengelolaan Perusahaan Daerah Isen Mulang Kota Palangkaraya.

Dalam hal keterbukaan transaparancy sejauh mana dilaksanakan di perusahaan berkaitan dengan keterbukaan akan informasi bagi pihak-pihak terkait, dijelaskan oleh Direktur Utama bahwa :

"Dalam hal pengambilan keputusan dan kebijakan perusahaan oleh manajemen sudah dilakukan secara terbuka, diadakan rapat terlebih dahulu lalu disampaikan kepada karayawan dan disampaikan ke pemangku kepentingan, mengenai tujuan perusahaan sudah ditetapkan dan diketahui oleh seluruh karyawan perusahaan, untuk informasi laporan keuangan sudah disampaikan secara terbuka disusun, diaudit dan disajikan sesuai standar akuntansi yang berlaku umum di Indonesia, namun untuk web atau blog perusahaan belum ada" (wawancara 13 Maret 2018).

Hal ini selaras dengan yang disampaikan oleh salah satu Unit Keungan menjelaskan bahwa :

"Pengambilan keputusan yang dilakukan oleh manajemen dilakukan secara terbuka dan dikomunikasikan kepada pemangku kepentingan, dan kami mengetahui tujuan perusahaan, untuk web atau blog perusahaan belum ada, seandainya ada tidak ada yang mengelola dan apa yang mau dipromosikan juga tidak ada, untuk informasi keuangan sudah sesuai dengan standar akuntansi yang berlaku umum di Indonesia dan diaudit oleh tim audit Independen"(Wawancara 13 Maret 2018).

Hasil dari wawancara dan pengamatan dapat ditarik kesimpulan bahwa prinsip keterbukaan atau transparancy belum terlaksana secara optimal dilihat dari belum adanaya web atau blog untuk memudahkan masyarakat mengakses informasi mengenai perusahaan daerah. Hal yang sama juga disampaikan oleh Dirut Teknik dan Pemasaran :

"web atau blog di perusahaan ini belum ada padahal sebenarnya itu perlu karena memudahkan untuk pemasaran produk daripada perusahaan, namun kami belum ada pemikiran kearah sana" (Wawancara 28 Maret 2018)

Hasil dari wawancara dan pengamatan dapat disimpulkan bahwa belum maksimal dalam melaksnakan keterbukaan informasi karena dari website lah masyarakat mudah mengakses dan mengetahui perkembangan serta jenis usaha yang dijalankan perusahaan dan hasil kinerja perusahaan. 
Perusahaan perlu menerapkan prinsip kejelasan Acountability yaitu kejelasan fungsi, pelaksanaan dan pertangungjawaban organ sehingga pengelolaan perusahaan terlaksana secara efektif, Tanggung jawab manajemen melalui pengawasan efektif berdasarkan keseimbangan kekuasaan antar manajer, pemegang saham, dewan komisaris, dan auditor, merupakan bentuk pertanggungjawaban manajemen kepada perusahaan dan pemegang saham disampaikan oleh Dirut PDIM :

"Perusahaan telah menentukan rincian tugas dan tanggung jawab masing-masing organ perusahaan dan semua karyawan sudah tau, adapaun mengenai tujuaan perusahan belum secara maksimal terlakasna karena perusahaan ini belum mampu mandiri dan masih menggantungkan penyertaan modal dan belum mampu memberi kontribusi yang maksimal terhadap PAD, sistem pengendalian yang efektif sudah ada jika ada yang melangar dan kinerjanya kurang akan kami beri sankasi” (Wawancara 13 Maret 2018).

Hal yang selras disampaikan Unit Keuangan PDIM :

"kejelasan mengenai rincian tugas dan tanggung jawab sudah di tetapkan namun untuk ukuran kinerja agar sesuai dengan nilai-nilai perusahaan sudah ditetakan dan sistem pengendalian sudah dilakasanakan" (Wawancara 13 Maret 2018).

Hal yang selaras disampaikan oleh Dirut Teknik :

"Perusahaan sudah menentukan rincian tugas dan tanggung jawab masing-masing organ perusahaan namun dalam pelaksanaanya belum maksimal".

Hasil dari wawancara dan pengamatan dapat ditarik kesimpulan bahwa dalam pelaksanaan Kejelasan Acountabilty belum terlaksana secara maksimal ini ditandai dengan belum terlaksananya rincian tugas dan tanggung jawab masing-masing organ dalam melakanakan pekerjaanya. Dalaam pengelolaan yang baik perusahaan harus menjalankan prisnsip Kesesuaian atau Responsibilty yaitu kesesuaian didalam pengelolaan perusahaan terhadap peraturan Perundang- undangan dan prinsip-prinsip korporasi yang sehat, Peran pemegang saham harus diakui sebagaimana ditetapkan oleh hukum dan kerjasama yang aktif antara perusahaan serta pemegang kepentingan dalam menciptakan kekayaan, lapangan kerja, dan perusahaan yang sehat dari aspek keuangan, disampaikan oleh Dirut PDIM:

"Dalam pelaksanaanya visi dan misi serta tujuan kami sudah berupaya melaksanakan dengan maksimal namun hasilnya masih belum memberikan kontribusi terhadap PAD karena belum pernah untung karena dikatakan perusahaan itu mendapat keuntungan jika hasil usaha sudah dikurang dengan modal dan sisanya itulah keuntugan, mengingat jumlah modal yang kami miliki jadi usaha yang mampu kita jalankan ya seperti ini dari pada tidak ada yang dikerjakan, ini sangat kami sayangkan terkait penyertaan modal yang diberikan itu untuk keseluruhan dari biaya operasional dan untuk modal usaha jadi, dana habis untuk biaya operasional saja, PDIM belum melaksanakan tanggung jawab sosial secara maksimal kepada masyrakat, belum melestarikan produk-produk lokal masih fokus usaha menjual material bangunan, karena mengalami kerugian maka perusahaan tidak membayar pajak penghasilan, perusahaan sudah menjlankan perusahaan sesuai dengan Perda yang berlaku" (Wawancara 13 Maret 2018). 
Dari hasil wawancara dapat disimpulkan bahwa selama beridirinya Perusahaan Daerah Isen Mulang belum pernah memberikan kontribusi terhadap PAD karena biaya penyertaan modal itu habis untuk biaya operasional dan PDIM juga pernah membrikan PAD namun itu manyalahi peraturan daerah dikarenakan kondisi Perusahaan masih merugi.

Perusahaan belum melakukan tanggug jawab sosial ditandai dnegan belumnya melesatrikan produk lokal dan juga perusahaan kondisi yang selalu merugi, dalam pengelolaan belum dilaksanakan sesuai dengan tujuan karena belum mampu memberi kontribusi terhdap PAD dan manfaatnya belum benar-benar dirasakan masyarakat, perusahaan belum pernah membayar pajak penghasilan karena kondisnya yang masih minus.

Dalam pengelolaan tata kelola perusahaan yang baik perusahaan harus menjalankan prisnip Independent yaitu keadaan di mana perusahaan dikelola secara profesional tanpa benturan kepentingan dan pengaruh/tekanan dari pihak manapun yang tidak sesuai dengan peraturan perundang-undangan dan prinsip-prinsip korporasi yang sehat. Yaitu mengenai bagai mana cara dalam penetapan dewan komisaris dan direksi serta jabatan penting lainya.

Untuk diangkat menjadi anggota direksi harus memenuhi sayarat-syarat umum dan khusus serta syarat-syarat lain yang diperlukan yaitu dalam Pasal 15 dan Pasal 16 dijelaskan bahawa calon Direksi harus sebagai warga negara indonesia, bertakwa kepada tuhan yang maha esa, setia dan taat kepada Pancasila dan Undang-Undang Dasar 1945, tidak pernah terlibat baik langsung maupun tidak langsung dalam setiap kegiatan yang mengkhianati NKRI yang berdasarkan Pancasila dan Undang-Undang Dasar 1945, dan tidak menjadi anggota organisasi terlarang, mempunyai rasa pengabdian kepada Nusa dan Bangsa serta kepada Pemerintah, tidak dicabut hak pilihnya berdasarkan Keputusan Pengadilan yang mempunyai kekuatan hukum tetap, sehat jasmani dan rohani serta berumur tidak lebih dari 60 (enam puluh) tahun, mempunyai kepribadian dan sifat-sifat kepemimpinan, mempunyai pengetahuan, kecakapan dan pengalaman pekerjaan yang cukup di bidang pengelolaan perusahaan, dan berwibawa serta jujur.

Dalam pengangkatan direksi dapat diangkat oleh Walikota atas usul Badan Pengawas dan untuk pertama kali di angkat langsung oleh Walikota dengan persetujuan DPRD Kota Palangka Raya, Masa jabatan Direksi ditetapkan selama 4 (empat) tahun dan dapat diangkat kembali untuk 1 (satu) kali masa jabatan dalam kedudukan yang sama, Pengangkatan untuk masa jabatan kedua sebagaimana dimaksud pada ayat (1) dilakukan, apabila Direksi terbukti mampu meningkatkan kinerja Perusahaan Daerah setiap tahun, Pengecualian dari ayat (1) apabila direktur yang bersangkutan diangkat menjadi Direktur Utama. dan untuk perencanaan kebutuhan pegawai atau karyawan ditentukan oleh direksi, yaitu dalam hal mengangkat, memberhentikan atau memindahtugaskan pegawai.

Dalam Pengelolaanya terhadap Perusahaan Daerah sebagai suatu Badan Usaha dilaksanakan oleh Dewan Direksi. Jumlah anggota Direksi paling banyak 5 (lima) orang serta seorang di antaranya diangkat sebagai Direktur Utama dan yang lainnya sebagai Direktur. Dalam melaksanakan Pengelolaan Perusahaan Daerah, Direksi dibantu oleh Kepala-kepala Unit dan Kepala-kepala Unit dibantu Kepala-kepala Seksi. Tanggung Jawab fungsional Perusahaan Daerah dilakukan oleh Direktur Utama kepada Walikota Palangka Raya. Dalam melaksanakan tugasnya Direktur bertanggung jawab kepada Direktur Utama dan Kepala Unit bertanggung jawab kepada Direktur. Hal ini selaras dengan hasil wawancara dengan Direktur Utama: 
"Menyatakan bahwa cara dalam penetapan Dewan Komisaris dan Direksi serta jabatan penting lainnya itu berdsarkan pada Perda yang berlaku. Direksi di angkat melalui beberapa tahap seperti diumumkan di koran dan saya di tes selama 5 hari segala macam tes dicoba disitu, tes kesehatan, psikotes, wawancara, dites oleh pengusaha oyang di anggap sukses di kota Plngka Raya, (inti pertanyaanya bagaimana untuk mengmbngkan PDIM dikota Pangka Raya)".(wawancara 13 Maret 2018)

Hal yang sama diungkapkan juga oleh salah satu anggota skretaris dari badan pengawas :

"Dalam penentuan direksi itu langsung kepala daerah melalui seleksi, tes pro pertes, lalau di rangking, dan diajukan ke kepala daerah". (wawancara 10 April 2018)

Maka dari hasil data wawancara tersebut dalam hal independent berjalan dengan baik dan tidak ada interfensi atau tekanan darimanapun hal ini sesuai dengan prinsip tata kelola perusahaan yang baik yaitu dengan adanya independen. Dan dalam penetepan direksi dijelaskan dalam perda Pasal 16.

Dalam hal independen jangan sampai ada pelimpahan tanggung jawab kepada rekan kerja yang satu dengan yang lain.Namun dalam pelaksanaan kedisplinan kerja di perusahaan daerah isen mulang masih kami temui adanya pelimpahan pekerjaan kepada rekan kerja ini selaras dengan yang disampaikan oleh Dirut PDIM :

"Ada yang merngkap jadi manajer toko agar tidak mencari karyawan lagi, Sebenarnya kurang karyawan tapi yasudahlah, manfaatkan yang ada". (wawancara 13 Maret 2018)

Hal ini selaras dengan yang disampaikan oleh salah satu karyawan perusahaan daerah isen mulang yaitu :

"Terkadang kami masih melakukan pekerjaan yang bukan kerjaaan kami, yaitu kami bagian keuangan masih membantu pekerjaan di bagian administrasi karena bagian administrasi memilki pekerjaan lain yaitu sebagai manajer toko, Karyawan merngkap sebnrnya tdak bagus dan tidak maksimal, namun frekuensinya tdak sering banget, jadi masih bisa kita handle". (wawancara 28 Maret 2018)

Hasil dari data wawancara dapat disimpulkan bahwa pelaksanaan independen masih beelum maksimal karena masih adanya pelimpahan tanggung jawab pekerjaan kepada rekan kerja. Dalam pengelolaan perusahaan tentu harus adanya suatu keadilan yang dirasakan seluruh pemangku kepentingan diperusahaan baik itu stake holders, karyawan dan juga masyarakat karena kita tau bahwa ini adalah perusda yang tujuan pendirianya muaranya ialah untuk kesejahteraan masyarakat. yaitu keadilan dan kesetaraan di dalam memenuhi

hak-hak Pemangku Kepentingan (stakeholders) yang timbul berdasarkan perjanjian dan peraturan perundang-undangan, Perlakuan yang sama terhadap pemegang saham, terutama kepada pemegang saham minoritas dan pemegang saham asing, dengan keterbukaan informasi yang penting serta melarang pembagian untuk pihak sendiri dan perdagangan saham oleh orang dalam. Hal ini disampaikan oleh Direktur Utama PDIM :

"Kami sudah sampaikan informasi yang akurat dan sesuai dan kami selalu terbuka menerima masukan atau menyampaikan pendapat dari pemangku kepentingan untuk kepentingan perusahaan" (Wawancara 13 Maret 2018). 
Hal yang selaras disampaikan oleh anggota badan pengawas :

"kami selaku badan pengawas selalu mendapatkan informasi yang akurat, kita kadanag sharing-sharing mengenai perushaan kedepan, setiap ada rapat kami di undang, dan laporanlaporan keuangan sudah mereka sampaikan, saya rasa perusahaan telah memberikan perlakuan yang sama terhadap pemangku kepentingan sesuai dengan manfaat dan kontribusi yang diberikan kepada perusahaan (Wawancara 10 April 2018)"

Dari hasil wawancara dana apengamatan dapat ditarik kesimpulan bahwa dalam hal keadilan penyampaian informasi kepada pemangku kepantingan sudah dilaksanakan dengan baik, mulai dari penyampaian informasi yang setara dan penyampaian saran pendapat bagi kepentingan perusahaan, tentu keadilan ini membawa hubungan yang harmonis untuk kelangsungan perusahaan. Kemudian bagaimana keadilam atau Fairness dengan karywan perusahaan mengenai bagaimana

sistem perekrutan pegawainya, pengembangan dan hak karyawan. Hal ini disampaikan oleh Direktur Utama PDIM :

"Kami sudah melakukan tahap-tahap yang idealis, kami informasikan ke publik pihak luar. Bahkan direksi pun memang di angkat melalui bbrpa tahap, diumumkan di koran, saya di tes selama 5 hari, segala macam tes dicoba dsitu, tes kesehatan, psikotes, wawancara, dites oleh pengusaha oyang di anggap sukses di kota Plngka Raya, (inti pertanyaanya bagaimana untuk mengmbngkan PDIM dikota Pangka Raya). Karywan juga begitu di tes lalau di magangkan kita tidak ada pendidikan khusus jadi saiapa yang punya minat dan bakat dan kemauan kita terima asalkan memenuhi sayarat yang sudah ditentukan“.(wawancara 13 Maret 2018).

Dari hasil data wawancara dan pengamatan dapat diambil kesimpulan bahwa dalam perekrutan karyawan di PDIM sudah berjalan akan tetapi yang menjadi pertimbangan ialah mereka tidak mementingkan unsur dari disiplin ilmu calon karyawan, asalkan karyawan disitu mampu dan mau bekerja keras itulah yang akan diterima menjadi karyawan di PDIM dan sumber penarikan pegawai tidak langsung mengarah kepublik namun lebih kepada kekeluargaan. Pertimbanganya ialah pada biaya, karena untuk melakukan perekrutan dan pencarian tehaga kerja yang baru tentu memerlukan biaya yang tidak sedikit, biaya yang ada selalu disampaikan bahwa habis untuk operasioal saja ini dikarenakan penyertaan modal yang diberikan oleh Pemko tidak ada pembagian antara modal usaha dengan biaya gaji pegawai .Jika dari keluarga atau rekan tidak ada yang mendaftar menjadi karyawan maka barulah mencari pekerja dengan pemberitahuan di media massa. Meskipun dari jalur teman atau keluarga tetap harus displin dan memilki kinerja yang baik.

Seluruh masyarakat di perbbolehkan untuk mendaftar sebagai calon pegawai diperusahaan sesuai dengan kebutuhan yang diperlukan. Untuk memberikan rasa keadilan maka pegawai diperusahaan perlu dilakukan pelatihan dan pengembangan kinerja artinya jangan hanya menuntut kinerja yang baik akan tetapi pelatihan dan pengembangan karyawan tidak dilaksankan, hal ini disampaikan oleh Direktur Utama PDIM :

"Mengenai pelatihan dan pengembangan pegawai di Perusahaan daerah Isen Mulang belum pernah dilakukan, sempat ada rencana namun tidak jadi, dan kami ingin melaksanakan itu namun terkendala dengan biayaa, karena mengadakan pelatihan dan pengembangan bukanlah dana yang sedikit". (wawancara 13 Maret 2018) 
Demikan pula disampaikan oleh salah satu karyawan atau Unit usaha :

"Selama saya bekerja disini Pelatihan dan pengembangan pegawai belum pernah dilaksanakan karena mengingat biaya yang mahal, biaya yang ada tdak cukup untuk melakukan pelatihan dan pengembangan”. (wawancara 28 Maret 2018)

Hasil dari data wawancara tersebut dapat diambil kesimpulan bahwa perusahaan belum menjalankan Pengelolaan Sumberdaya Manusia dengan baik, yaitu ditandai dengan belum dilakukanya pelatihan dan peengembangan pegawai dikarenakan biaya yang mahal. Telah sama kita ketahui bahwa Pelatihan dan Pengembangan ini sangat penting untuk keberlangsungan perusahaan dalam persaingan yang saat ini semakin ketat. Jika tidak dilakukan Pelatihan dan pengembangan pegawai maka pengetahuan disiplin ilmu pegawai tidak berkembang, tidak memilki motivasi kerja yang tinggi dalam pemikiranya hanya yang penting bekerja dan mendapat balas jasa atau gaji tidak lagi memikirkan perkembangan perusahaan kedepan, yang ditandai dengan menurunya produktivitas kerja, kualitas kerja menurun, sikap moral dan semangat bekerja berkurang, keinginan untuk berprestasi berkurang, menurunya perkembangan pegawai dan perusahaan mengalami keusangan jenis usaha yang akibatnya ketidak siapan untuk bersaing. Adapun biaya yang dikelaurkan untuk pelatihan dan pengembangan karyawan itu merupakan investasi jangka panjang perusahaan, jadi sebenarnya tidaklah merugi jika perusahaan menggelontorkan dana yang cukup banyak untuk kegiatan pelatihan dan pengembangan pegawai.

Pegembangan atau pelatihan merupakan hal yang sangat penting mengingat manusia adalah mahluk yang dinamis yang menyukai dengan sesuatu yang baru dan perkembangan dunia saat ini sangatlah pesat dan cepat maka sebuah perusahaan memerlukan Sumber Daya Manusia yang cepat dan tanggap dalam melihat suatu kondisi. Bukan menambah atau mengganti pegawai yang ada namun memaksimalkan pegawai yang ada untuk tercapainya tujuan perusahaan yaitu dengan di adakanya pelatihan atau pengembangan pengetahuan.

Dalam hal keadilan tentu hak dan kewajiban karywan harus terpenuhi yaitu mengenai hak kesehatan dan tunjangan, hal ini disampaikan oleh Pak Dirut PDIM disampaikan bahwa :

"Ya itu tadi bahwa biaya tunjangan dan kesehatan masuk biaya operasional, karena ini merupakan kewajiban kami selaku perusahaan ya wajib dan harus memberikan gaji kepada karyawan dan membayrkan BPJS yaitu kesehatan karyawan perusahaan,a artinya karyawan sudah mendapatkan hak kesehatan dan tunjangan”(Wawancara 13 Maret 2018).

Hal yang sama disampaikan oleh karyawan Unit Keuangan disampaikan bahwa :

"Hak kesehatan dan tunjangan alhamdulillah sudah dipenuhi oleh perusahaan, karena kewajiban suatau perusahaan, kalau tidak ya kami tuntut itu karena itu hak kami, masa iya kita kerja ngga di bayar"

Hasil dari wawancara dan pengamatan dapat ditarik kesimpulan bahwa beberapa hal mengenai keadilan sudah dilaksanakan namun ada hal yang belum terlaksana mengenai perekrutan pegawai dan pelatihan dan pengembangan, disampaikan bahwa dalam hal perekrutan atau penyebaran informasinya kurang luas masih sistem kekeluargaan dan juga selama ini belum pernah dilasanakanya pelatihan dan pengemabangan pegawai tentu ini lah yang akan menghambat kinerja perusahaan, perusahaan tidak akan mampu bersaing jika tidak memilki sumberdaya yang baik, yang memilki inovasi yang baru pengetahuan yang luas dan tentunya kinerjanya akan rendah jika tidak diseleksi dengan baik dalam perekrutan dan jika tdak dilakukann pelatihan dan pengembangan. 
Berdasarkan hasil penelitian dilapangan sesuai dengan landasan teori Tata Kelola Perusahaan Yang Baik Good Corporate Governance mengenai pengelolaan Perusahaan Daerah Isen Mulang Kota Palangka Raya.

\section{Keterbukaan Transparancy}

Keterbukaan dalam melaksanakan proses pengambilan keputusan dan keterbukaan dalam mengungkapkan informasi materiil dan relevan mengenai perusahaan, Hak pemegang saham, yang harus diberi informasi benar dan tepat waktu mengenai perusahaan, dapat berperan serta dalam pengambilan keputusan mengenai perubahan mendasar atas perusahaan dan memperoleh bagian keuntungan perusahaan (Ari Gayo:2013). Pengungkapan yang akurat dan tepat waktu serta transparansi mengenai semua hal penting bagi kinerja perusahaan, kepemilikan, serta pemegang kepentingan (Sutedi : 2012).

Pelaksanaan prinsip keterbukaan atau transparancy belum terlaksana secara optimal dilihat dari belum adanya web atau blog untuk memudahkan masyarakat mengakses informasi mengenai perusahaan daerah karena dari website lah masyarakat mudah mengakses dan mengetahui perkembangan serta jenis usaha yang dijalankan perusahaan dan hasil kinerja perusahaan.

\section{Kejelasan Accountability}

Akntabilitasi adalah kejelasan fungsi, pelaksanaan dan pertanggungjawaban organ sehingga pengelolaan perusahaan terlaksana secara efektif (Ari Gayo:2013). Akuntabilitas adalah tanggung jawab manajemen melalui pengawasan efektif berdasarkan keseimbangan kekuasaan antar manajer, pemegang saham, dewan komisaris, dan auditor, merupakan bentuk pertanggungjawaban manajemen kepada perusahaan dan pemegang saham (Sutedi : 2012).

Dalam pelaksanaan Kejelasan Acountabilty belum terlaksana secara maksimal ditandai dengan belum terlaksananya rincian tugas dan tanggung jawab masing-masing organ dalam melaksanakan pekerjaanya.

\section{Kesesuaian Responsibility}

Pertanggungjawaban atau kesesuaian adalah dalam pengelolaan perusahaan terhadap peraturan Perundang-undangan dan prinsip-prinsip korporasi yang sehat (Ari Gayo:2013). Bentuk dari pertannggung jawaban adalah peran pemegang saham harus diakui sebagaimana ditetapkan oleh hukum dan kerjasama yang aktif antara perusahaan serta pemegang kepentingan dalam menciptakan kekayaan, lapangan kerja, dan perusahaan yang sehat dari aspek keuangan.

Dalam pelaksanaanya mengenai pertanggungjawaban dan kesesuaian selama beridirinya Perusahaan Daerah Isen Mulang belum memberikan kontribusi terhadap PAD secara maksimal karena biaya penyertaan modal itu habis untuk biaya operasional dan PDIM juga pernah memberikan PAD namun itu manyalahi peraturan daerah dikarenakan kondisi perusahaan masih merugi. Perusahaan belum melakukan tanggug jawab sosial ditandai dnegan belumnya melesatrikan produk lokal, dalam pengelolaan belum dilaksanakan sesuai dengan tujuan dari diberidirkannya Perusahaan Daerah Isen Mulang dan manfaatnya belum benar-benar dirasakan masyarakat, perusahaan belum pernah membayar pajak penghasilan, keseluruhan di atas karena kondisnya perusahaan yang masih minus. 


\section{Kemandirian Independent}

Kemandirian atau Independent adalah keadaan di mana perusahaan dikelola secara profesional tanpa benturan kepentingan dan pengaruh/tekanan dari pihak manapun yang tidak sesuai dengan peraturan perundang-undangan dan prinsip-prinsip korporasi yang sehat(Ari Gayo:2013).

Dalam pelaksanaan kemandirian atau Indpendent di perusahaan daerah isen mulang belum maksimal dilaksanakan ini ditandai dengan adanya pelimpahan tanggung jawab antara yang satu dengan yang lain adapaun yang lainya mengenai pengambilan keputusan sudah baik dengan tandai tidak adanya intervensi dari pihak manapun bebas dari kepentingan dan perusahaan juga diberi kebebasan untuk melakukan jenis usaha, namun permasalahanya terkendala pada biaya yaitu modal usaha artinya modal yang diberikan kurang, sebagian besar dipergunakan ntuk biaya operasional. kemudian dalam pengangkatan direksi sudah baik dengan dilaksanakanya car-cara yang ideal terlebih dahulu untuk mendapatkan sumberdaya manusia yang profesional.

\section{Keadilan Fairness}

Kewajaran adalah keadilan dan kesetaraan di dalam memenuhi hak-hak pemangku kepentingan (stakeholders) yang timbul berdasarkan perjanjian dan peraturan perundangundangan (Ari Gayo:2013). kewajaran atau keadilan adalah perlakuan yang sama terhadap pemegang saham, terutama kepada pemegang saham minoritas dan pemegang saham asing, dengan keterbukaan informasi yang penting serta melarang pembagian untuk pihak sendiri dan perdagangan saham oleh orang dalam (Sutedi : 2012).

Dalam pelaksanaan keadilan Fairness bahwa dalam hal keadilan penyampaian informasi kepada pemangku kepentingan sudah dilaksanakan dengan baik, mulai dari penyampaian informasi yang setara dan penyampaian saran pendapat bagi kepentingan perusahaan, tentu keadilan ini membawa hubungan yang harmonis untuk kelangsungan perusahaan kemudian bagaimana keadilam atau Fairness dengan karyawan perusahaan mengenai bagaimana sistem perekrutan pegawainya, pengembangan dan hak karyawan.

dalam perekrutan karyawan di PDIM sudah berjalan dengan baik akan tetapi yang menjadi pertimbangan ialah mereka tidak mementingkan unsur dari disiplin ilmu calon karyawan, asalkan karyawan disitu mampu dan mau bekerja keras itulah yang akan diterima menjadi karyawan di PDIM dan sumber penarikan pegawai tidak langsung mengarah kepublik namun lebih kepada kekeluargaan, Jika dari keluarga atau rekan tidak ada yang mendaftar menjadi karyawan maka barulah mencari pekerja dengan pemberitahuan di media massa, meskipun dari jalur teman atau keluarga tetap harus displin dan memilki kinerja yang baik, pertimbanganya ialah pada biaya, karena untuk melakukan perekrutan dan pencarian tenaga kerja yang baru tentu memerlukan biaya yang tidak sedikit disampaikan bahwa biaya yang ada selalu habis untuk operasioal ini dikarenakan penyertaan modal yang diberikan oleh Pemko tidak ada pembagian antara modal usaha dengan biaya gaji pegawai .

Seluruh masyarakat di perbbolehkan untuk mendaftar sebagai calon pegawai diperusahaan sesuai dengan kebutuhan yang diperlukan untuk memberikan rasa keadilan maka pegawai diperusahaan perlu dilakukan pelatihan dan pengembangan kinerja artinya jangan hanya menuntut kinerja yang baik akan tetapi pelatihan dan pengembangan karyawan belum dilaksanakan. 
Perusahaan belum menjalankan Pengelolaan Sumberdaya Manusia dengan baik, yaitu ditandai dengan belum dilakukanya pelatihan dan peengembangan pegawai dikarenakan biaya yang mahal. Telah sama kita ketahui bahwa Pelatihan dan Pengembangan ini sangat penting untuk keberlangsungan perusahaan dalam persaingan yang saat ini semakin ketat, jika tidak dilakukan Pelatihan dan pengembangan pegawai maka pengetahuan disiplin ilmu pegawai tidak berkembang, tidak memilki motivasi kerja yang tinggi dalam pemikiranya hanya yang penting bekerja dan mendapat balas jasa atau gaji tidak lagi memikirkan perkembangan perusahaan kedepan, yang ditandai dengan menurunya produktivitas kerja, kualitas kerja menurun, sikap moral dan semangat bekerja berkurang, keinginan untuk berprestasi berkurang, menurunya perkembangan pegawai dan perusahaan mengalami keusangan jenis usaha yang akibatnya ketidak siapan untuk bersaing adapun biaya yang dikelaurkan untuk pelatihan dan pengembangan karyawan itu merupakan investasi jangka panjang perusahaan, jadi sebenarnya tidaklah merugi jika perusahaan menggelontorkan dana yang cukup banyak untuk kegiatan pelatihan dan pengembangan pegawai.

Pegembangan atau pelatihan merupakan hal yang sangat penting mengingat manusia adalah mahluk yang dinamis yang menyukai dengan sesuatu yang baru dan perkembangan dunia saat ini sangatlah pesat dan cepat maka sebuah perusahaan memerlukan sumber daya manusia yang cepat dan tanggap dalam melihat suatu kondisi bukan menambah atau mengganti pegawai yang ada namun memaksimalkan pegawai yang ada untuk tercapainya tujuan perusahaan yaitu dengan di adakanya pelatihan atau pengembangan pengetahuan.

\section{KESIMPULAN}

Berdasarkan hasil penelitian dan pembahsan yang telah dilakukan dalam penelitian ini, maka dapat disimpulkan bahwa Pengelolaan Perusahaan Daerah Isen Mulang Kota Palangka Raya belum dikelola dengan maksimal. Hal yang di tandai dengan belum terlaksananya tata kelola perusahaan yang baik (Good Corporate Governance) secara maksimal.

\section{Keterbukaan Transparancy}

Pelaksanaan prinsip keterbukaan atau transparancy belum terlaksana secara optimal dilihat dari belum adanya web atau blog untuk memudahkan masyarakat mengakses informasi mengenai perusahaan daerah karena dari website lah masyarakat mudah mengakses dan mengetahui perkembangan serta jenis usaha yang dijalankan perusahaan dan hasil kinerja perusahaan.

\section{Kejelasan Acountability}

Pelaksanaan Kejelasan Acountabilty belum terlaksana secara maksimal ini ditandai dengan belum terlaksananya rincian tugas dan tanggung jawab masing-masing organ dalam melaksanakan pekerjaanya. 


\section{Keseusaian Responsibility}

Pelaksanaanya mengenai pertanggunga jawaban dan kesesuaian selama beridirinya Perusahaan Daerah Isen Mulang belum pmemberikan kontribusi terhadap PAD secara maksimal karena biaya penyertaan modal itu sebagian besarnya untuk biaya operasional dan PDIM juga pernah memberikan hasil usaha untuk PAD namun itu manyalahi peraturan daerah dikarenakan kondisi Perusahaan masih belum mendapat keuntungan . Perusahaan belum melakukan tanggug jawab sosial ditandai dnegan belumnya melesatrikan produk lokal, dalam pengelolaan belum dilaksanakan sesuai dengan tujuan dari diberidirikanya PDIM di lingkungan Kota Palangka Raya dan manfaatnya belum benar-benar dirasakan masyarakat, perusahaan belum pernah membayar pajak penghasilan karena kondisnya yang masih minus.

\section{Kemandirian Independent}

Pelaksanaan kemandirian atau Indpendent di Perusahaan Daerah Isen Mulang belum maksimal dilaksanakan ini ditandai dengan adanya pelimpahan tanggung jawab antara yang satu dengan yang lain adapaun yang lainya mengenai pengambilan keputusan sudah baik dengan tandai tidak adanya intervensi dari pihak manapun bebas dari kepentingan dan perusahaan juga diberi kebebasan untuk melakukan jenis usaha, namun permasalahanya terkendala pada biaya yaitu modal usaha, artinya modal yang diberikan kurang, sebagian besar dipergunakan ntuk biaya operasional. kemudian dalam pengangkatan direksi sudah baik dengan dilaksanakanya car-cara yang ideal terlebih dahulu untuk mendapatkan sumberdaya manusia yang profesional.

\section{Keadilan Fairness}

Pelaksanaan Keadilan Fairness belum terlaksana dengan maksimal yaitu ditandai dengan belum dilaksanakanya pelatihan dan pengembangan pegawai dikarenakan biaya yang mahal telah sama kita ketahui bahwa Pelatihan dan Pengembangan ini sangat penting untuk keberlangsungan perusahaan dalam persaingan yang saat ini semakin ketat, jika tidak dilakukan Pelatihan dan pengembangan pegawai maka pengetahuan disiplin ilmu pegawai tidak berkembang, tidak memilki motivasi kerja yang tinggi yang ditandai dengan menurunya produktivitas kerja, kualitas kerja menurun, sikap moral dan semangat bekerja berkurang, adapun biaya yang dikelaurkan untuk pelatihan dan pengembangan karyawan itu merupakan investasi jangka panjang perusahaan, jadi sebenarnya tidaklah merugi jika perusahaan menggelontorkan dana yang cukup banyak untuk kegiatan pelatihan dan pengembangan pegawai dan dalam perekrutan pegawai belum diumumkan ke masyarakat luas masih pada sistem kekeluargaan karena terkendala dengan biaya. 


\section{DAFTAR PUSTAKA}

Antonius Alijoyo dan Subarto Zain,2004. Komisaris Independen, Penggerak Praktik GCG di Perusahaan, Jakarta : Indeks Kelompok Gramedia.

Amin Widjaja Tunggal, 2008.Corporate Social Responsibility (CSR), Jakarta.

Ari Gayo, Ahyar, 2013, Pengelolaan BUMD Berdasarkan Prinsip Tata Kelola yang Baik. Jakarta : Badan Pembinaan Hukum.

Bakat, Muhammad, dkk. 1989. Ekonomi Koperasi Edisi 2. Jakarta: PT Intan Pariwara.

Bungin, Burhan. 2007. Penelitian Kualitatif : Komunikasi, Ekonomi, Kebijakan Publik, dan Ilmu Sosial Lainnya. Jakarta: Kencana Prenada Media Group.

Bungin, Burhan. 2010.Metode Penelitian Kualitatif. Rajawali Pers. Jakarta.

Dewi, Elita. (2002). Identifikasi Sumber Pendapatan Asli Daerah Dalam Rangka Pelaksanaan Otonomi Daerah.

Jurnal Ilmu Sosial Dan Ilmu Politik Universitas Sumatera Utara, (online) http://repository.Usu.ac.id/ bitstream/123456789/1261/1/manajemen-elita. pdf,pada tanggal 10 Desember.

Hasan, Iqbal. 2002. Pokok - Pokok Materi Metodologi Penelitian dan Aplikasinya. Jakarta : Ghalia Indonesia.

Moleong, Lexy J. (2007) Metodologi Penelitian Kualitatif, Penerbit PT Remaja Rosdakarya Offset, Bandung.

Owa da Santo, Maria Fransiska 2013 “Pentingnya Prinsip Good Corporate Governace Dalam Pengelolaan Perusahaan Daerah”, Jurnal GCG No. I him 25-32.

Permata Budi Asri, Dyah, "Pelaksanaan Good Corporate Governance Dalam UU Nomor 40 Tahun 2007 Tentang PT', tersedia di web site http://janabadra.cic.id/ujb/00-2411-7401-pdf) ,di akses pada tanggal 20 Januari 2018.

Sutedi,Adrian. 2012. Good Corporate Governance. Jakarta : Sinar Grafika.

Sugiyono, 2009. Metode Penelitian Kuantitatif, Kualitatif dan R\&D, Bandung : Alfabeta.

Peraturan Walikota Palangkaraya Nomor 43 Tahun 2011 Tentang Organiasasi dan Tata Kerja Perusahaan Daerah Isen Mulang.

Peraturan Daerah Kota Palangka Raya Nomor 05 Tahun 2010 Tentang Pembentukan Perusahaan Daerah Di Lingkungan Pemerintah Kota Palangka Raya 